\title{
Copper Oxide Decorated Zinc Oxide Nanostructures for the Production of a Non-Enzymatic Glucose Sensor
}

\author{
Chung-En Cheng ${ }^{1}$, Sripansuang Tangsuwanjinda ${ }^{2}$, Hsin-Ming Cheng ${ }^{2,3, * \mathbb{D}}$ and Po-Han Lee ${ }^{4, *}$ \\ 1 Taipei Municipal Heping High School, Taipei 106, Taiwan; jordancheng93816@gmail.com \\ 2 Organic Electronics Research Center, Ming Chi University of Technology, New Taipei City 243, Taiwan; \\ stang.suwanjinda@gmail.com \\ 3 Department of Electronic Engineering, Ming Chi University of Technology, New Taipei City 243, Taiwan \\ 4 Affiliated Senior High School of National Taiwan Normal University, Taipei 106, Taiwan \\ * Correspondence: SMCheng@mail.mcut.edu.tw (H.-M.C.); phlee@ntut.edu.tw (P.-H.L.)
}

Citation: Cheng, C.-E.;

Tangsuwanjinda, S.; Cheng, H.-M.; Lee, P.-H. Copper Oxide Decorated Zinc Oxide Nanostructures for the Production of a Non-Enzymatic Glucose Sensor. Coatings 2021, 11, 936. https: / / doi.org/10.3390/ coatings11080936

Academic Editor: Ioana

Daniela Dulama

Received: 6 July 2021

Accepted: 31 July 2021

Published: 4 August 2021

Publisher's Note: MDPI stays neutral with regard to jurisdictional claims in published maps and institutional affiliations.

Copyright: (c) 2021 by the authors. Licensee MDPI, Basel, Switzerland. This article is an open access article distributed under the terms and conditions of the Creative Commons Attribution (CC BY) license (https:// creativecommons.org/licenses/by/ $4.0 /)$.

\begin{abstract}
The glucose concentration in human blood can have a worrisome impact on human health, so the distribution of blood glucose contaminants in the human body is an important indicator that can be used to monitor diabetes. Diabetes affects many parts of the human body, such as neurological impairment, erectile dysfunction, and hardening of the arteries resulting in organ loss. In this study, cyclic voltammetry $(\mathrm{CV})$ was used to process the electrical properties of a solution by preparing electrodes with $\mathrm{CuO}$ nanoparticles modified $\mathrm{ZnO}$ tetrapod nanostructures deposited on fluorinedoped tin oxide glass $(\mathrm{CuO} / \mathrm{ZnO} / \mathrm{FTO})$. The measurements were processed in glucose solutions of different concentrations purposing for developing the sensitivity of the sensor. Different immersion times in the precursor copper sulfate solution were also used for preparing the electrode and carried out for electrochemical studies to adjust the electrode capability. The modified electrode, which was immersed in copper sulfate for $30 \mathrm{~s}$, was efficient in detecting glucose molecules in different concentrations at the potential of $+0.6 \mathrm{~V}$. The rising slope is strongly and positively correlated with the concentration of glucose. One of the significant results is the indication that glucose concentration is linearly proportional to the current value of CV. After the measurement test with the addition of interference, the sensor can still identify the glucose concentration in the solution without being affected. This result proves that the sensor has considerable potential for developing into a highperformance non-enzymatic glucose sensor.
\end{abstract}

Keywords: cyclic voltammetry; glucose sensor; copper oxide; zinc oxide; nanostructures

\section{Introduction}

Glucose monitoring using sensors is an active research area because high levels of glucose in the blood could cause diabetes. The reported surge in the global population with diabetes is related to inappropriate food culture in modern society [1]. The disease is found to have greatly contributed to various health problems and is a leading cause of death [2,3]. To study the impact of diabetes, the development of glucose sensors is of vital importance in diabetes control, with regular measurement and monitoring. Since Clark and Lyons developed the first enzymatic electrode in the 1960s [4], there have been many impressive advances in the design and use of glucose biosensors. Nanomaterials have played a crucial role in developing the glucose observation system [5-7] because of their large surface area and high electrochemical activity [8,9]. In the past few years, most studies have focused on enzyme-based electrochemical sensors [10-13]. However, the enzyme-containing glucose sensor faces many problems, such as being affected by high temperatures and humidity, which causes a loss of measurement accuracy and decreases sensitivity [14,15]. Therefore, a low-cost, non-enzymatic glucose sensor has been developed with high stability and repeatability [16-18]. It has been reported that nanomaterials used for electrochemical sensors also have effective electron transfer from the electrocatalyst to 
the conductive electrode substrate [19]. Nanostructured transition-metal oxides, which exhibit better catalytic activity in alkaline media, have been used to create high-performance non-enzymatic glucose sensors [18-22].

$\mathrm{ZnO}$ is an n-type semiconductor, which is especially non-toxic, low cost, and easy to synthesize. Its good optical and electrical properties have shown great advantages for non-enzymatic sensor applications in biomolecule detection $[23,24]$. In addition, $\mathrm{ZnO}$ nanostructured materials have a larger scale that can effectively increase the electrocatalytic glucose response [24]. It is reported that $\mathrm{ZnO}$ nanostructures can provide a suitably extensive surface for modification by other materials. Among them, $\mathrm{ZnO}$ nanostructures are also divided into various shapes such as nanowires [25], nanorods [24], nano-pillars [26], and tetrapod nanostructures [27]. In addition, the hybrid structure of zinc oxide and other materials is more helpful to improve its corresponding application characteristics, such as hybrid structures of wool-ball-like $\mathrm{ZnO}$ with carbon nanotubes [28], honeycomb-like $\mathrm{ZnO}$ with multiwalled carbon nanotube [29], and hollow $\mathrm{ZnO}$ nanostructures with $\mathrm{ZnCo}_{2} \mathrm{O}_{4}$ for gas sensing [30]; the hybrid structures of zinc oxide nanoparticle and graphene for photocatalysis [31]; the hybrid structures of hierarchical $\mathrm{ZnO}$ nanostructures and silver nanoparticle for surface-enhanced Raman scattering [32,33]. In this study, $\mathrm{ZnO}$ tetrapod nanostructures were unitized to provide a template for the electrode because of their four-pillar structure with a larger scale than other structures [34,35]. Interestingly, many different nanostructured materials modified on $\mathrm{ZnO}$ have shown to enhance electrocatalysis [23], given that heterogeneous materials have the ability to transfer electrons more quickly [36]. In addition to being cheaper than noble metals for catalyzing glucose, $\mathrm{CuO}$ is a $p$-type semiconductor that has the excellent ability to catalyze glucose. The outstanding electrochemical catalytic performance of $\mathrm{CuO}$ nanostructures makes $\mathrm{CuO}$-modified $\mathrm{ZnO}$ tetrapods a potential material for the development of glucose biosensors [37,38]. Currently, the processing of $\mathrm{ZnO}$ materials is mature, and includes methods such as the hydrothermal method, sputtering deposition [39], and direct current (DC) thermal plasma reaction method $[40,41]$. In this study, $\mathrm{ZnO}$ tetrapod nanostructures were obtained by a DC thermal plasma reaction method because this method can effectively allow for low-cost, continuous mass production $(\mathrm{kg} \cdot \mathrm{level} / \mathrm{h})$ of high-purity, non-aggregated $\mathrm{ZnO}$ powders. The accurate control of the chemical composition, phase purity, structure, shape, size, and other properties of the nano-powder results in a highly efficient process for preparing $\mathrm{ZnO}$ [42].

The $\mathrm{ZnO}$ template formed from tetrapod nanostructures ( $\mathrm{ZnO}-\mathrm{T})$ was prepared on fluorine-doped tin oxide-coated (FTO) glass by screen-printing, and $\mathrm{CuO}$ nanoparticles ( $\mathrm{CuO} \mathrm{NPs}$ ) were modified on the surface of the $\mathrm{ZnO}$ nanostructure using the precursor method to enhance the electrochemical activity for glucose detection via higher surface area and direct electron transfer. Another reason for using this method is that the electrode requires the growth of nanostructures directly on its surface to connect the nanostructures to the electrode seamlessly. After completing the preparation, field-emission scanning electron microscopy (FESEM), energy dispersive spectroscopy (EDS), and X-ray diffraction (XRD) were used to assess the quality of the materials. Finally, the CuO NP-modified $\mathrm{ZnO}-\mathrm{T}$ grown on the FTO electrode $(\mathrm{CuO} / \mathrm{ZnO} / \mathrm{FTO})$ was ready to be effectively used to detect glucose concentration by electrochemical cyclic voltammetry to promote fast electron transfer. This modified electrode also showed excellent electrochemical performance for glucose detection, with high reproducibility, repeatability, and stability. Therefore, the non-enzymatic sensor proved promising for sensing applications in real-time samples.

\section{Materials and Methods}

Chemicals and Instruments Copper (II) sulfate pentahydrate $\left(\mathrm{CuSO}_{4} \cdot 5 \mathrm{H}_{2} \mathrm{O}, 98+\%\right)$, sodium hydroxide $(\mathrm{NaOH}, 97+\%)$, and sodium chloride $(\mathrm{NaCl}, 97+\%)$ were ordered from UNI-ONWARD CORP (New Taipei City, Taiwan). D (+)-Glucose (97.5\%) was obtained from Merck KGaA (Darmstadt, Germany). All chemicals were used as received, without further purification. All electrochemical experiments were conducted at room temperature and performed on a PGSTAT204 electrochemical workstation system (Metrohm, Herisau, 
Switzerland). A classical three-electrode cell was used, with a Pt wire counter electrode, a $\mathrm{CuO} / \mathrm{ZnO} / \mathrm{FTO}$ working electrode, and $\mathrm{Ag} / \mathrm{AgCl}$ as the reference electrode. All potentials were reported with reference to the $\mathrm{Ag} / \mathrm{AgCl}$ electrode.

The morphologies of the $\mathrm{ZnO} / \mathrm{FTO}$ and $\mathrm{CuO} / \mathrm{ZnO} / \mathrm{FTO}$ samples were examined using a field emission scanning electron microscope (FESEM) (JSM-7610F Plus, JEOL, Tokyo, Japan). The SEM was also equipped with an energy-dispersive X-ray spectroscopic (EDS) system for elemental analysis.

Fabrication of ZnO Nanostructural Template on FTO the production of tetrapod-like $\mathrm{ZnO}$ nanoparticles can easily reach $1 \mathrm{~kg} / \mathrm{h}$ via the DC thermal plasma reaction method. The detailed synthetic procedure and its relative characterizations have been discussed in previous studies [41]. The $\mathrm{ZnO}$ paste for screen-printing was prepared typically by mixing tetrapod-like $\mathrm{ZnO}$ nanoparticles, ethyl cellulose (EC) and terpineol (anhydrous, \#86480, Fluka, Buchs, Switzerland). The detailed procedure is as follows: EC (5-15 mPas, \#46070, Fluka) and EC (30-70 mPas, \#46080, Fluka) were dissolved in ethanol to yield a 10 wt.\% solution, and then $12 \mathrm{~g}$ EC (5-15) and $12 \mathrm{~g} \mathrm{EC} \mathrm{(30-70)} \mathrm{were} \mathrm{added} \mathrm{to} \mathrm{a} \mathrm{round-}$ bottomed rotavap flask containing $12 \mathrm{~g} \mathrm{ZnO}$ nanoparticles and $25 \mathrm{~g}$ terpineol. The mixture paste was dispersed in an ultrasonic bath, and a rotary evaporator (BUCHI V850, BÜCHI, Flawil, Switzerland) was used to remove residual ethanol and water from the mixture. The final formulations of the $\mathrm{ZnO}$ pastes were prepared using a three-roll mill (E50, EXAKT, Oklahoma City, OK, USA). The ZnO templates were prepared by screen-printing $0.28 \mathrm{~cm}^{2}$ $\mathrm{ZnO}$ films with a $20 \mu \mathrm{m}$ thickness on FTO substrates (Nippon Sheet Glass Co. Ltd., $10 \Omega / \mathrm{sq}$, $3 \mathrm{~mm}$ thickness, Tokyo, Japan). The films were then gradually heated at $350{ }^{\circ} \mathrm{C}$ in the presence of $\mathrm{O}_{2}$ supply for $30 \mathrm{~min}$, to remove any organic material in the paste, and then they were cooled to room temperature for further use.

Synthesis of $\mathrm{CuO}$ NPs on $\mathrm{ZnO}$ nanostructures a precursor solution was prepared by dissolving $\mathrm{CuSO}_{4} \cdot 5 \mathrm{H}_{2} \mathrm{O}(1.8 \mathrm{~g})$ in $25 \mathrm{~mL}$ of deionized (DI) water, and the electrodes grown with $\mathrm{ZnO} / \mathrm{FTO}$ were soaked in the prepared solution for different time intervals (such as 10, 20, and 30 s); these samples are denoted as CZF-10, CZF-20 and CZF-30, respectively. After growing $\mathrm{CuO}$ on $\mathrm{ZnO}-\mathrm{T} / \mathrm{FTO}$, the residue was cleaned with DI water and dried with a nitrogen gun. Finally, the $\mathrm{CuO}$ NP-modified ZnO-T grown on the FTO electrode was sintered at $400{ }^{\circ} \mathrm{C}$ for $2 \mathrm{~h}$. Briefly, the copper ions attached to the surface of zinc oxide will form copper oxide compounds during heating, and excess sulfate ions will also form sulfur dioxide at high temperatures and dissipate in the atmosphere. Then, the completed electrode can be used for electrochemical experiments and glucose sensing analysis. The whole process has been presented in Scheme 1.

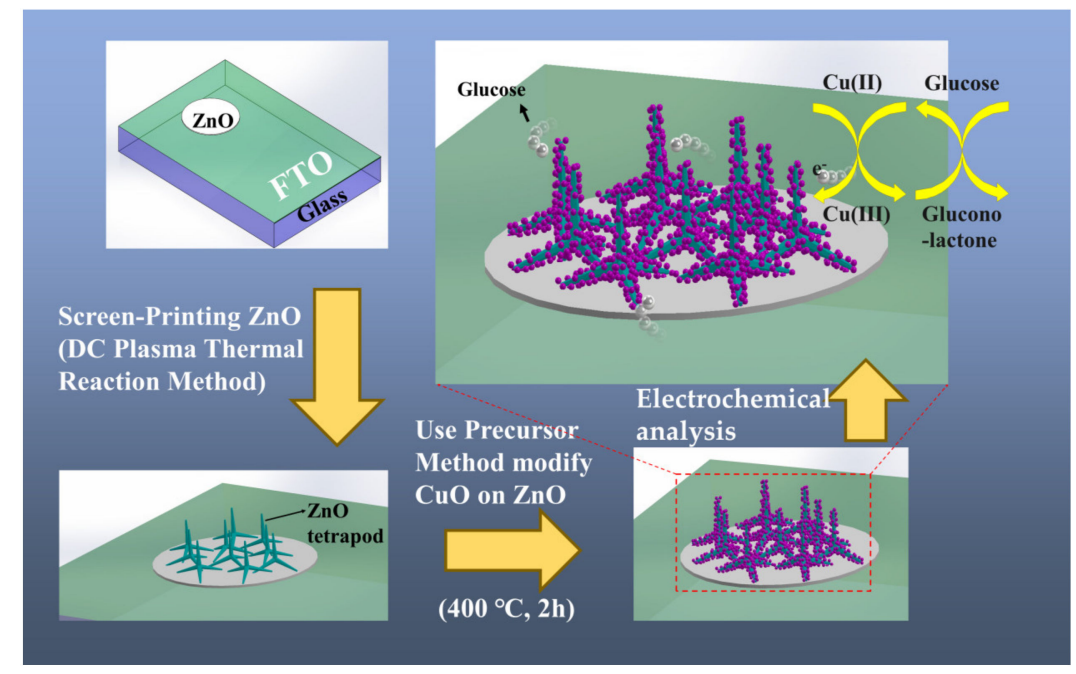

Scheme 1. Schematic illustration of the synthesis of a non-enzymatic glucose sensor electrode. 


\section{Results \\ 3.1. Synthesis and Structural Properties}

FESEM was used to evaluate the morphology of $\mathrm{ZnO}$ electrodes before and after $\mathrm{CuO}$ modification. As shown in Figure 1a, most of the original $\mathrm{ZnO}$ nanostructures are polymorphic, consisting of nanopillars, branched- and tetrapod-shaped $\mathrm{ZnO}$ powders. The axial length is about 100-400 nanometers, and the radial direction is about 30-80 nanometers. The crystalline structure is very good. The $\mathrm{ZnO}$ powder was deposited on the FTO in a porous form through the screen-printing process. Such a porous structure also allows the precursor solution of $\mathrm{Cu}$ ions to infiltrate smoothly to achieve a uniform surface modification. As shown in Figure $1 \mathrm{~b}$, after the $\mathrm{CuO}$ modification, the rough morphology of the $\mathrm{CuO} / \mathrm{ZnO} / \mathrm{FTO}$ electrode was observed due to the decoration of the surface with $\mathrm{CuO}$ nanoparticles as compared to the smooth surface of original $\mathrm{ZnO}$ structures. It can be observed that the $\mathrm{CuO}$ nanoparticles on the surface are not very obvious, indicating that the $\mathrm{CuO}$ nanoparticles mostly belong to nanocrystalline or in an amorphous form due to our short-time heat treatment process. However, the EDS analysis of Figure 1c can still confirm that there is a considerable proportion of $\mathrm{Cu}$ signals in the electrodes. A small sulfur signal appears in the spectrum, which is related to the residual $\mathrm{CuSO}_{4} \cdot 5 \mathrm{H}_{2} \mathrm{O}$ in the precursor or undissipated solid $\mathrm{SO}_{2}$. EDS mapping of Figure 1e-g are revealed to further analyze the elemental distribution of $\mathrm{Cu}, \mathrm{Zn}$, and $\mathrm{O}$, respectively, in the $\mathrm{CuO} / \mathrm{ZnO} / \mathrm{FTO}$ electrode in the corresponding area of Figure $1 \mathrm{~d}$. It can be confirmed again that the $\mathrm{CuO}$ modification on the surface of zinc oxide is very successful and uniform.
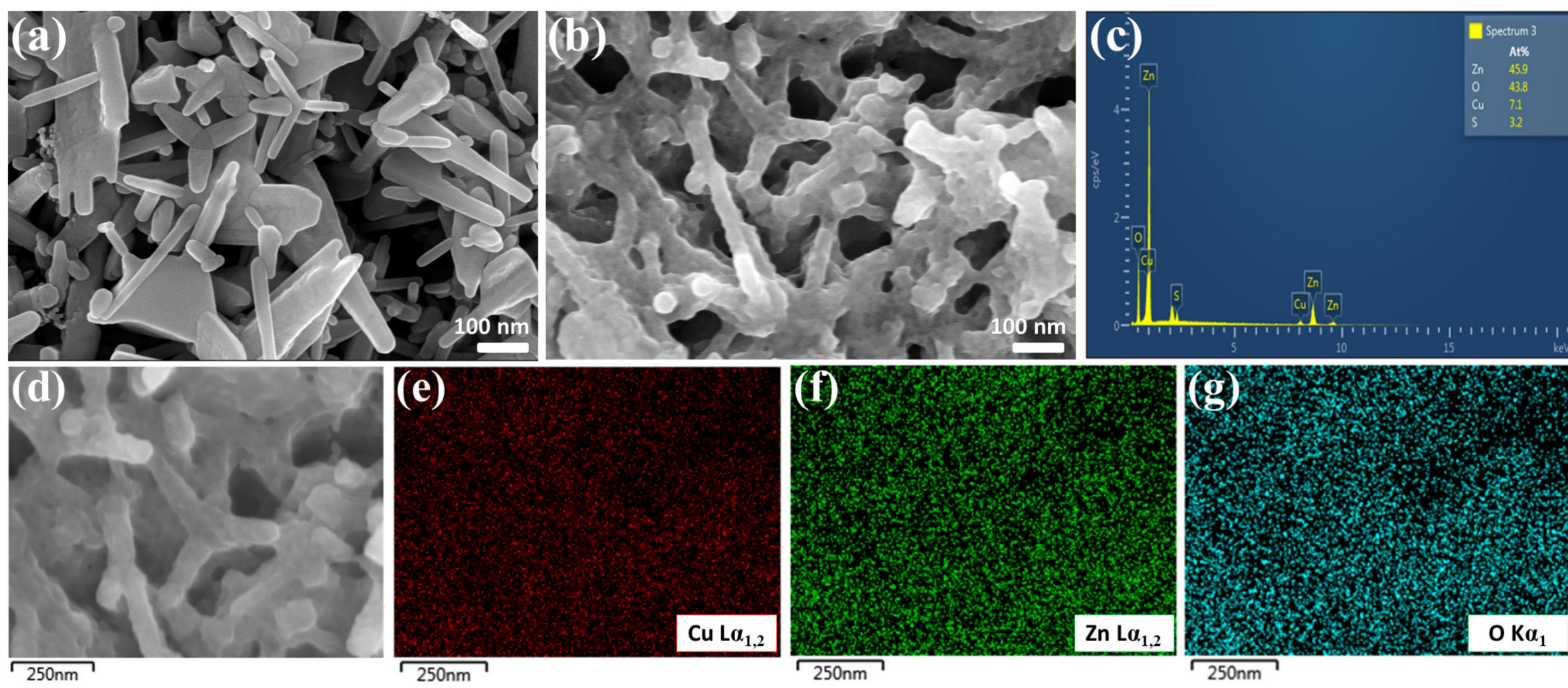

Figure 1. FESEM morphologies of ZnO-T electrode (a) before and (b) after $\mathrm{CuO}$ modified; (c) EDS spectrum of $\mathrm{CuO} / \mathrm{ZnO} / \mathrm{FTO}$ electrode; (e-g) elemental maps of $\mathrm{Cu}, \mathrm{Zn}$ and $\mathrm{O}$ in the $\mathrm{CuO} / \mathrm{ZnO} / \mathrm{FTO}$ electrode from the corresponding region of image $(\mathbf{d})$.

The crystal structure analysis was carried out by XRD analysis. The room temperature XRD spectrum result of the $\mathrm{CuO} / \mathrm{ZnO} / \mathrm{FTO}$ electrode is shown in Figure 2. The strong diffraction peaks in the range of $25^{\circ}$ to $40^{\circ}$ were attributed to the hexagonal wurtzite structure of $\mathrm{ZnO}$ (JCPDS 36-1451), and the tetragonal $\mathrm{SnO}_{2}$ (JCPDS 46-1088) from FTO substrate we used. It is especially worth noting that from the refinement of the XRD patterns no lattice distortion and the appearance of impurity phases were found, which means the $\mathrm{ZnO}$ still maintains the hexagonal phase with the space group of $P 6_{3} m c$ (186) after the $\mathrm{CuO}$ modification process. We further zoomed in on the XRD spectrum. The inset of Figure 2 showed that there were additional weak peaks around the strong diffraction peaks at positions $32.5^{\circ}, 35.4^{\circ}, 35.5^{\circ}, 38.7^{\circ}$, and $38.9^{\circ}$ which can be analyzed and indexed as (110), (002) (11ī), (111), and (200) crystal planes of monoclinic CuO (JCPDS 48-1548), respectively. These diffraction signals attributed to $\mathrm{CuO}$ are not very obvious and belong 
to the nanocrystalline. The XRD results are further confirmed to be consistent with the FESEM observations.

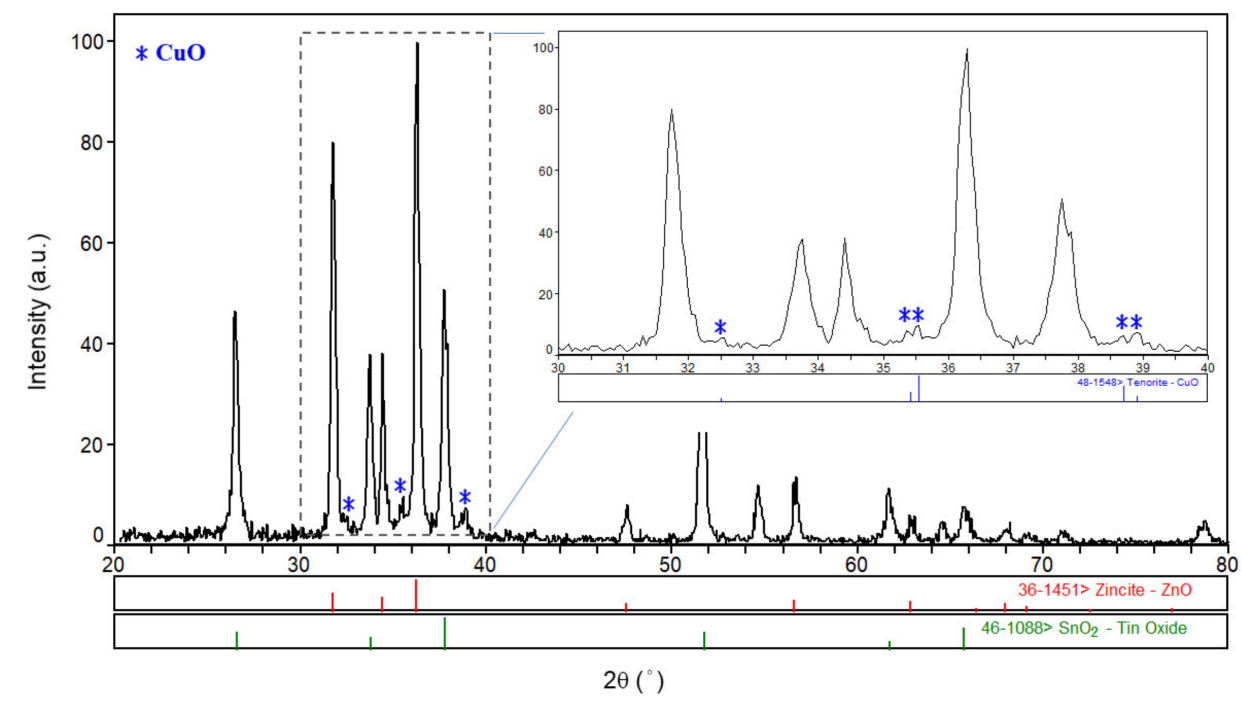

Figure 2. XRD pattern of $\mathrm{CuO} / \mathrm{ZnO} / \mathrm{FTO}$ electrode (CZF-30). The inset depicts the magnified curve for the clearer diffraction peaks of $\mathrm{CuO}$.

\subsection{Electrocatalytic Oxidation of Glucose Using $\mathrm{CuO} / \mathrm{ZnO} / \mathrm{FTO}$}

In cyclic voltammetry $(\mathrm{CV})$ measurements, $\mathrm{CuO} / \mathrm{ZnO} / \mathrm{FTO}$ was mainly used as the working electrode, and the potential range of the experiment was 0.0 to $0.8 \mathrm{~V}$, with a scan rate of $100 \mathrm{mV} / \mathrm{s}$. Three electrolytes were used, from which the most suitable was determined: an acid electrolyte $\left(\mathrm{H}_{3} \mathrm{PO}_{4}(\mathrm{aq})\right)$, a neutral electrolyte $(\mathrm{NaCl}(\mathrm{aq}))$, and an alkaline electrolyte $(\mathrm{NaOH}(\mathrm{aq}))$. As $\mathrm{NaCl}$ undergoes a redox reaction when voltage is applied, chlorine volatilizes in air, while $\mathrm{H}_{3} \mathrm{PO}_{4}$ destroys the material of the working electrode. $\mathrm{NaOH}$ was chosen for the experiment as it is a non-destructive substrate that does not undergo redox reactions when a voltage is applied. Figure 3 a presents a comparison of ZnO-T/FTO and phase control relays (CZF-30) when using $0.1 \mathrm{M} \mathrm{NaOH}$ as the electrolyte. During the measurement, the final value of current will be stable after several cyclic measurements and the current can reached $2000 \mu \mathrm{A}$ at $+1.0 \mathrm{~V}$ while we adjusted the proper electrolyte concentration. The effective conductivity of the electrode can be clearly seen through the modified $\mathrm{CuO}$ on $\mathrm{ZnO} / \mathrm{FTO}$, proving that $\mathrm{NaOH}(\mathrm{aq})$ is the most suitable for protecting the system, and for improving its conductivity. The following is the reaction of $\mathrm{CuO} / \mathrm{ZnO} / \mathrm{FTO}$ in an alkaline environment:

(I). $\mathrm{CuO}+\mathrm{OH}^{-} \rightarrow \mathrm{CuOOH}+\mathrm{e}^{-}$or $\mathrm{CuO}+\mathrm{H}_{2} \mathrm{O}+2 \mathrm{OH}^{-} \rightarrow \mathrm{Cu}(\mathrm{OH})_{4}^{-}+\mathrm{e}^{-}$

(II). $\mathrm{Cu}(\mathrm{III})+$ Glucose $+\mathrm{e}^{-} \rightarrow$ Gluconolactone $+\mathrm{Cu}$ (II)

(III). Gluconolactone $\rightarrow$ Gluconic acid (hydrolysis)

Figure $3 \mathrm{~b}$ shows the result with the $\mathrm{NaOH}$ electrolyte $(0.1 \mathrm{M})$ after mixing with glucose $(0.1 \mathrm{mM})$, which appears at the $+0.6 \mathrm{~V}$ potential mark. Looking at the current line without glucose solution (Figure $3 \mathrm{a}$ ), the results clearly confirm that the $\mathrm{ZnO}-\mathrm{T}$ electrode modified with $\mathrm{CuO}$ NPs effectively improves the oxidizing ability of the copper oxide, resulting from the large number of $\mathrm{CuO}$ NPs growing on the large surface area of $\mathrm{ZnO}-\mathrm{T}$. Figure 3c shows the current feedback status in the scan rate range of $0.0-1.0 \mathrm{~V} \cdot \mathrm{s}^{-1}$. As the value of the scan rate increases, the current feedback at the anode also increases proportionally, following the scan rate. Figure 3d shows a linear graph from changing the current response with increasing scan rate, indicating the surface control of the electrochemical process over the $\mathrm{CuO} / \mathrm{ZnO} / \mathrm{FTO}$ electrode. 


\subsection{Amperometric Response with Glucose}

According to the $\mathrm{CV}$ results, Figure 4a shows the result when glucose is added to the $0.1 \mathrm{M} \mathrm{NaOH}$ electrolyte. The current value rose at the $+0.6 \mathrm{~V}$, and this trend was not observed in the absence of glucose. The pattern can be clearly identified based on the current response, which changes at $+0.6 \mathrm{~V}$ when modulating the concentration of additional glucose aqueous solution, proving that the current response at $+0.6 \mathrm{~V}$ was caused by the interaction of the $\mathrm{CuO} / \mathrm{ZnO} / \mathrm{FTO}$ electrode with glucose in the electrocatalytic solution. Figure $4 \mathrm{~b}$ shows the coefficient line analysis of current values at different glucose concentrations and voltages. The results show that the correlation coefficients $\left(R^{2}\right)$ for $+0.5 \mathrm{~V},+0.6 \mathrm{~V}$, and $+0.7 \mathrm{~V}$ are $0.92,0.94$, and 0.89 , respectively, which is a strongly positive correlation. Therefore, the potential at $+0.6 \mathrm{~V}$ can be used to determine the current response and identify the related glucose concentration, as well as the increase in the current value resulting from that glucose concentration. The coefficient line analysis with different glucose concentrations at a potential of $+0.6 \mathrm{~V}$ displays a linear regression line until a glucose concentration of $7 \mathrm{mM}$. All these results remained stable after several measurements, indicating the high stability, high sensitivity, and high electrocatalytic characteristics of this sensor. These results suggest that the tetrapod structure of $\mathrm{ZnO}$ provides a large surface area to attach more $\mathrm{CuO}$ NPs on the surface, thus greatly improving the catalytic performance of $\mathrm{CuO} / \mathrm{ZnO} / \mathrm{FTO}$ in glucose detection. The electrode preparation process uses the precursor method to grow $\mathrm{CuO}$ NPs directly on the surface of the electrode through soaking, which enables more $\mathrm{CuO} N \mathrm{NPs}$ to undergo direct redox reactions with the glucose in solution. The advantages of the $\mathrm{CuO} / \mathrm{ZnO} / \mathrm{FTO}$ electrode are its low cost, low risk, and ease of use. Therefore, the sensor used in this study has many characteristics that can be developed to make it a high-performance glucose sensor.
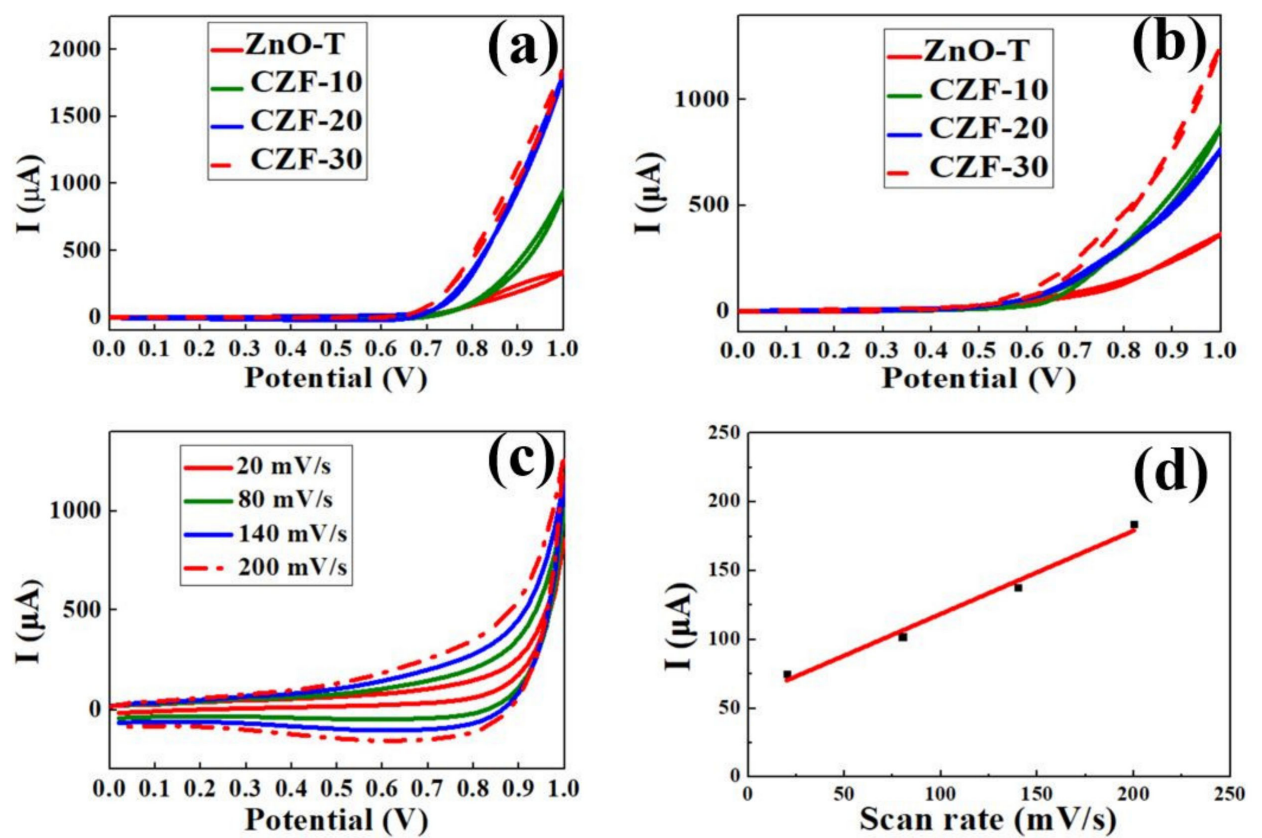

Figure 3. (a) CVs of ZnO-T electrode (red), CZF-10 (green), CZF-20 (blue), CZF-30 (red dotted line) run at $100 \mathrm{mV} / \mathrm{s}$ in $0.1 \mathrm{M} \mathrm{NaOH}$ (b) CVs of ZnO-T electrode (red), CZF-10 (green), CZF-20 (blue), CZF-30 (red dotted line) run at $100 \mathrm{mV} / \mathrm{s}$ in $0.1 \mathrm{M} \mathrm{NaOH}$ add $0.1 \mathrm{mM}$ glucose. (c) CVs of the CZF-30 in $0.1 \mathrm{M} \mathrm{NaOH}$ containing $1 \mathrm{mM}$ glucose at different scan rates from 20 to $200 \mathrm{mV} / \mathrm{s}$. (d) shows the anodic peak current vs. scan rate.

The measured glucose concentration in this study is close to $7 \mathrm{mM}$ with the limit of detection (LOD) of about $0.0139 \mathrm{mM}$ (the human blood glucose concentration range is 1.5$10 \mathrm{mM}$ ). Compared with [16,43-45], our research electrode can distinguish a wider range of 
glucose concentrations within a response time of approximately $1.5 \mathrm{~s}$. This is quicker than the response time reported by others, indicating the sensor's considerable potential for future practical application as a high-reliability sensor in hematology. In addition to fixing the instability of the enzyme-containing test paper and its susceptibility to environmental changes (easy to oxidize), it also demonstrated reproducibility, high stability, and high sensitivity, which are requirements for a high-performance glucose sensor.
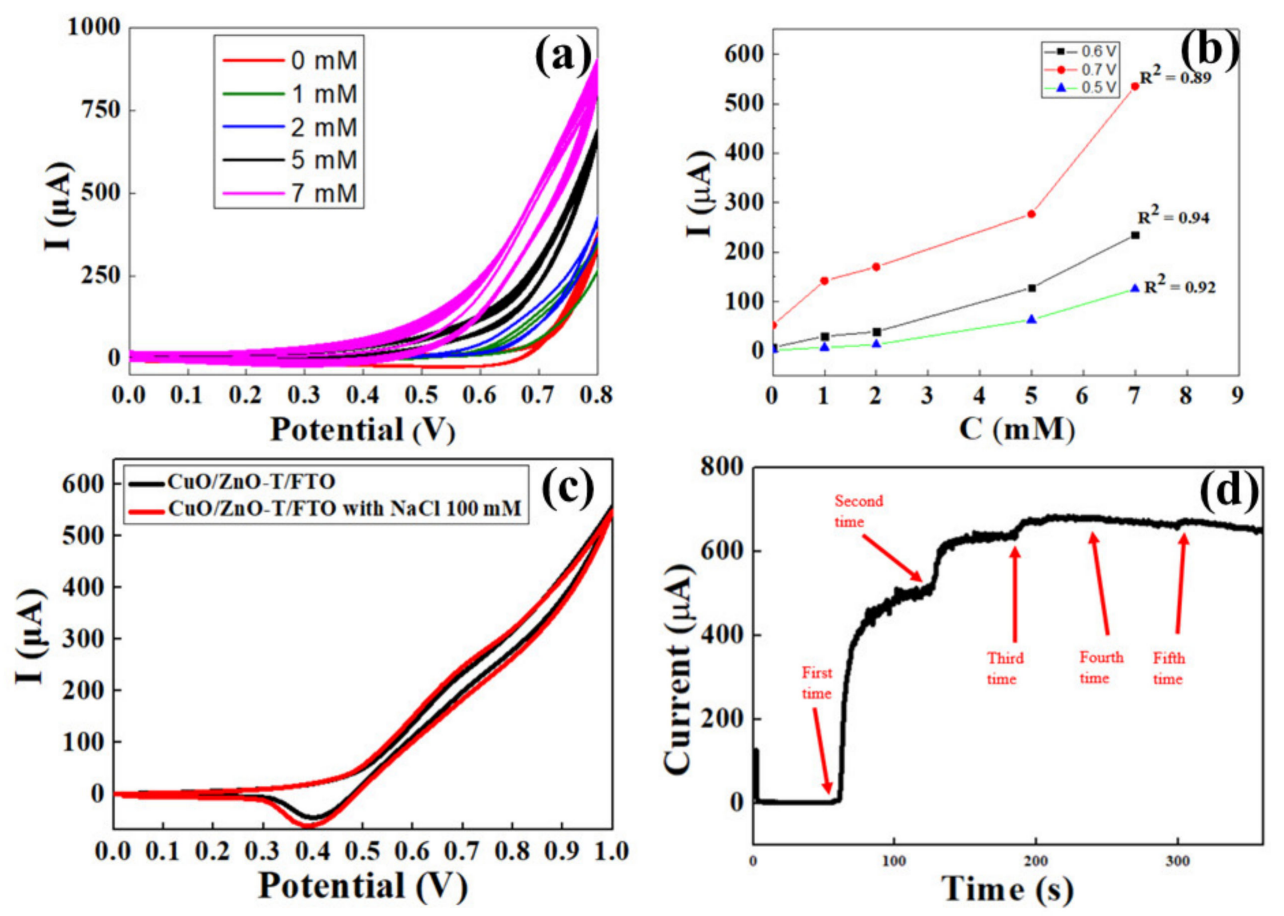

Figure 4. (a) CV curves in the presence of different glucose concentrations with a CZF-30 electrode (scan rate, $100 \mathrm{mV} / \mathrm{s}$ ). (b) Corresponding calibration plot of peak current versus scan rate. (c) Responses of the sensor to $5 \mathrm{mM}$ glucose in $0.1 \mathrm{M} \mathrm{NaOH}$ solution with and without $100 \mathrm{mM} \mathrm{NaCl}$. (d) Responses of the sensor in $0.1 \mathrm{M} \mathrm{NaOH}$ with the successive addition of 5 individual doses of $5 \mathrm{mM}$ glucose solutions.

\subsection{Anti-Interference Test}

According to previous reports, electrochemical glucose sensors using electrodes made of copper-related materials are prone to lose activity due to the effect of chloride poisoning [46], because the inhibition of chloride ion adsorption is a non-negligible problem for glucose sensing and the chloride concentration in blood can be as high as $100 \mathrm{mM}$. Therefore, we used an electrolyte containing chloride (saline in this case) to analyze the response of the electrode we made. As shown in Figure 4c, the interfering substances in the human blood were added for the compared CV measurements. It can be seen that the addition of interfering substances does not cause much difference in the current response at a potential of $+0.6 \mathrm{~V}$; therefore, this sensor can certainly avoid the problem of interfering substances and still provide accurate measurements of glucose concentration.

\subsection{Amperometric Response of $\mathrm{CuO} / \mathrm{ZnO} / \mathrm{FTO}$ Electrode at $+0.6 \mathrm{~V}$}

According to Figure $4 \mathrm{~d}$, it can be seen that, initially, adding a $5 \mathrm{mM}$ glucose solution every $60 \mathrm{~s}$ caused the value of the current to rise immediately, although this rise stopped when $5 \mathrm{mM}$ of glucose solution was added several times (after the fifth time). This is because the present sensor design could have a glucose concentration range beyond what can accurately be detected. The $25 \mathrm{mM}$ glucose concentration is already beyond the linear range of perceptible detection. However, the result still proves with certainty that glucose can indeed generate a current response at a potential of $+0.6 \mathrm{~V}$. 


\section{Discussion}

In this study, we synthesized a low-cost, high-benefit material, using a simple process to prepare copper oxide-modified zinc oxide nanostructures. FESEM showed the presence of copper oxide nanoparticles and zinc oxide tetrapods. After modification, the zinc oxide material exhibited good electrocatalytic performance when used as an electrode to detect glucose. When applied even to low concentrations of glucose solution, it can produce differences in the current response of the $\mathrm{CV}$ curve. After adding other interfering substances in the human blood to test-measure, the sensor in this study could still accurately identify the correct glucose concentration, without being affected by the adsorption of chloride ions. At the same time, the copper oxide-modified zinc oxide material has a lower cost and better performance than other precious metal electrodes. Its advantages, which include high efficiency, stability, accuracy, and reproducibility, give it considerable potential for future application in the development of a blood glucose sensor. Although some of the sensing values are not very superior, the overall device structure can be optimized, such as by improving the crystallization characteristics of $\mathrm{CuO}$ or reusing a smaller size of zinc oxide to increase the specific surface area. The analytical performances of enzyme-free glucose sensors by utilized various $\mathrm{CuO}$ and corresponding support metal/oxide nanostructure in terms of sensitivity, response time, and linear working range were compared with this present work $[19,22,44,47-49]$ and are summarized in Table 1 . This blood glucose concentration detection mechanism was carried out electrochemically and could be one of the best choices to respond to modern society's emphasis on resource reduction as environmental protection awareness rises.

Table 1. Comparison of various non-enzymatic electrochemical sensors based on $\mathrm{CuO}$ electrodes.

\begin{tabular}{|c|c|c|c|c|c|}
\hline Electrode & Methods & $\begin{array}{c}\text { Sensitivity } \\
\left(\mu \mathrm{A} \cdot \mathrm{cm}^{-2} \cdot \mathrm{mM}^{-1}\right)\end{array}$ & $\begin{array}{l}\text { Linear Range } \\
\text { (mM) }\end{array}$ & $\begin{array}{l}\text { Response } \\
\text { Time (s) }\end{array}$ & Ref. \\
\hline $\mathrm{CuONWs} / \mathrm{Cu}$ foam & Electrochemical anodization & 2217.4 & $0.001-18.8$ & $\mathrm{~N} \cdot \mathrm{A}$. & [19] \\
\hline CuO-ZnO NRs/FTO & Solution Process & 2961.8 & $0.001-8.45$ & $<2$ & [22] \\
\hline Ag NPs/CuO NFs-ITO & Electrospinning & 1347 & $0.0005-0.55$ & $<3$ & [46] \\
\hline Mesoporous $\mathrm{CuO}$ & Nanocasting method & 26.6 & $0.1-3$ & $\mathrm{~N} \cdot \mathrm{A}$. & {$[47]$} \\
\hline $\begin{array}{l}\mathrm{CuO} \mathrm{NFs} \text { and } \\
\mathrm{NPs} / \mathrm{TiO}_{2} \mathrm{NTs}\end{array}$ & $\begin{array}{l}\text { Seed-mediated synthesis } \\
\text { method }\end{array}$ & 79.9 & $0-2.0$ & $<3$ & {$[48]$} \\
\hline $\mathrm{CuO} /$ graphene & Microwave-assisted synthesis & 37.63 & 5-14 & 1 & [49] \\
\hline $\mathrm{CuO} / \mathrm{ZnO} / \mathrm{FTO}$ & Solution Process & 1142 & Up to 7 & $\sim 1.5$ & This work \\
\hline
\end{tabular}

NWs: nanowires; NRs: nanorods; NFs: nanofibers; NPs: nanoparticles; NTs: nanotubes.

\section{Conclusions}

In this study, the voltametric electrodes as the non-enzymatic glucose sensors can be synthesized successfully by immersing the $\mathrm{ZnO}$ nanostructures into the precursors with copper ions via the simple solution method. The $\mathrm{CuO}$ nanocrystallines were uniformly decorated on the surface of the tetrapod-like $\mathrm{ZnO}$ nano-powders which were obtained by the direct current plasma method. The support $\mathrm{ZnO}$ electrode not only manifests stable crystallization characteristics, but also provide a porous structure and a huge specific surface area due to the formation of a network structure through the screen-printing process. In the glucose experiment using the three-electrode method, the completed $\mathrm{CuO} / \mathrm{ZnO} / \mathrm{FTO}$ electrode is used as the working electrode during measurements. The measurement data shows that this electrode has high catalytic performance for the detection of glucose concentrations, and that the preparation of the $\mathrm{CuO} / \mathrm{ZnO} / \mathrm{FTO}$ electrode is simple and low-cost. This heterogeneous material effectively increased the current value generated by the electrocatalytic glucose at a potential of $+0.6 \mathrm{~V}$, and the current value of $\mathrm{R}^{2}=0.94$ (up to $7 \mathrm{mM}$ glucose). Further, it was found to yield more stable and credible data, and to be a reusable measurement system. This result was obtained by a combination of heterogeneous oxide materials $(\mathrm{CuO} / \mathrm{ZnO})$ used in glucose sensors to provide a new field of vision. 
Author Contributions: Conceptualization, H.-M.C. and P.-H.L.; Data curation, C.-E.C. and S.T.; Formal analysis, C.-E.C. and S.T.; Project administration, H.-M.C.; Supervision, H.-M.C. and P.-H.L.; Writing-original draft, C.-E.C.; Writing-review and editing, H.-M.C. All authors have read and agreed to the published version of the manuscript.

Funding: This research was funded by Ministry of Science and Technology, Taiwan. Grant Nos. are: MOST 109-2112-M-131-001 and MOST 110-2112-M-131-002-MY3.

Institutional Review Board Statement: Not applicable.

Informed Consent Statement: Not applicable.

Data Availability Statement: The data presented in this study are available on request from the corresponding author.

Acknowledgments: All authors are grateful to the assistances of Rahul Ram Panjalingam for his help in the setup of electrochemical equipment.

Conflicts of Interest: The authors declare no conflict of interest.

\section{References}

1. Yoo, E.-H.; Lee, S.-Y. Glucose biosensors: An overview of use in clinical practice. Sensors 2010, 10, 4558-4576. [CrossRef] [PubMed]

2. World Health Organization (WHO). Global Report on Diabetes; WHO: Geneva, Switzerland, 2016.

3. Jacobson, A.M.; Musen, G.; Ryan, C.M.; Silvers, N.; Cleary, P.; Waberski, B.; Burwood, A.; Weinger, K.; Bayless, M.; Dahms, W.; et al. Longterm effect of diabetes and its treatment on cognitive function. N. Engl. J. Med. 2007, 356, 1842-1852.

4. Clark, L.C., Jr.; Lyons, C. Electrode systems for continuous monitoring in cardiovascular surgery. Automated and semi-automated systems in clinical chemistry. Ann. N. Y. Acad. Sci. 1962, 102, 29-45. [CrossRef]

5. Ahmad, R.; Ahn, M.S.; Hahn, Y.-B. Fabrication of a non-enzymatic glucose sensor field-effect transistor based on verticallyoriented $\mathrm{ZnO}$ nanorods modified with $\mathrm{Fe}_{2} \mathrm{O}_{3}$. Electrochem. Commun. 2017, 77, 107-111. [CrossRef]

6. Solanki, P.R.; Kaushik, A.; Agrawal, V.V.; Malhotra, B.D. Nanostructured metal oxide-based biosensors. NPG Asia Mater. 2011, 3 , 17-24. [CrossRef]

7. Liu, A. Towards development of chemosensors and biosensors with metaloxide-based nanowires or nanotubes. Biosens. Bioelectron. 2008, 24, 167-177. [CrossRef]

8. Misson, M.; Zhang, H.; Jin, B. Nanobiocatalyst advancements and bioprocessing applications. J. R. Soc. Interface 2015, $12,20140891$. [CrossRef] [PubMed]

9. Zhu, C.; Yang, G.; Li, H.; Du, D.; Lin, Y. Electrochemical sensors and biosensors based on nanomaterials and nanostructures. Anal. Chem. 2015, 87, 230-249. [CrossRef]

10. Wang, J. Electrochemical glucose biosensors. Chem. Rev. 2008, 108, 814-825. [CrossRef] [PubMed]

11. Oliver, N.S.; Toumazou, C.; Cass, A.E.G.; Johnston, D.G. Glucose sensors: A review of current and emerging technology. Diabet. Med. 2009, 26, 197-210. [CrossRef] [PubMed]

12. Shao, Y.; Wang, J.; Wu, H.; Liu, J.; Aksay, I.; Lin, Y. Graphene based electrochemical sensors and biosensors: A review. Electroanalysis 2010, 22, 1027-1036. [CrossRef]

13. Zhang, M.; Liao, C.; Mak, C.H.; You, P.; Mak, C.L.; Yan, F. Highly sensitive glucose sensors based on enzyme-modified whole-graphene solution-gated transistors. Sci. Rep. 2015, 5, 8311. [CrossRef] [PubMed]

14. Tang, J.; Wang, Y.; Li, J.; Da, P.; Genga, J.; Zheng, G. Sensitive enzymatic glucose detection by $\mathrm{TiO}_{2}$ nanowire photoelectrochemical biosensors. J. Mater. Chem. A 2014, 2, 6153-6157. [CrossRef]

15. Gao, Z.D.; Qu, Y.; Li, T.; Shrestha, N.K.; Song, Y.-Y. Development of amperometric glucose biosensor based on prussian blue functionalized $\mathrm{TiO}_{2}$ nanotube arrays. Sci. Rep. 2014, 4, 6891. [CrossRef]

16. Zhou, C.; Xu, L.; Song, J.; Xing, R.; Xu, S.; Liu, D.; Song, H. Ultrasensitive non-enzymatic glucose sensor based on threedimensional network of $\mathrm{ZnO}-\mathrm{CuO}$ hierarchical nanocomposites by electrospinning. Sci. Rep. 2014, 4, 7382. [CrossRef] [PubMed]

17. Ahmad, R.; Vaseem, M.; Tripathy, N.; Hahn, Y.-B. Wide linear-range detecting nonenzymatic glucose biosensor based on CuO nanoparticles inkjet-printed on electrodes. Anal. Chem. 2013, 85, 10448-10454. [CrossRef] [PubMed]

18. Mani, S.; Vediyappan, V.; Chen, S.M.; Madhu, R.; Pitchaimani, V.; Chang, J.; Liu, S.-B. Hydrothermal synthesis of NiWO $\mathrm{N}_{4} \mathrm{crystals}$ for high performance nonenzymatic glucose biosensors. Sci. Rep. 2016, 6, 24128. [CrossRef] [PubMed]

19. Li, Z.; Chen, Y.; Xin, Y.; Zhang, Z. Sensitive electrochemical nonenzymatic glucose sensing based on anodized CuO nanowires on three-dimensional porous copper foam. Sci. Rep. 2015, 5, 16115. [CrossRef]

20. Luo, X.; Zhang, Z.; Wan, Q.; Wu, K.; Yang, N. Lithium-doped NiO nanofibers for non-enzymatic glucose sensing. Electrochem. Commun. 2015, 61, 89-92. [CrossRef]

21. Liu, Z.; Yadian, B.; Liu, H.; Liu, C.; Zhang, B.; Ramanujan, R.V.; Huang, Y. Fabrication of hybrid CuO/Pt/Si nanoarray for non-enzymatic glucose sensing. Electrochem. Commun. 2013, 33, 138-141. [CrossRef]

22. Ahmad, R.; Ahn, M.; Bhat, K.S.; Mahmoudi, T.; Wang, Y.; Yoo, J.; Kwon, D.; Yang, H.; Hahn, Y. Highly efficient non-enzymatic glucose sensor based on $\mathrm{CuO}$ modified vertically-grown $\mathrm{ZnO}$ nanorods on electrode. Sci. Rep. 2017, 7, 5715. [CrossRef] 
23. Ahmad, R.; Tripathy, N.; Hahn, Y.-B. High-performance cholesterol sensor based on the solution-gated field effect transistor fabricated with $\mathrm{ZnO}$ nanorods. Biosens. Bioelectron. 2013, 45, 282-286. [CrossRef]

24. Hahn, Y.-B.; Ahmad, R.; Tripathy, N. Chemical and biological sensors based on metal oxide nanostructures. Chem. Commun. 2012, 48, 10369-10385. [CrossRef]

25. Zhang, Y.; Ram, M.K.; Stefanakos, E.K.; Goswami, D.Y. Synthesis, characterization, and applications of ZnO nanowires. J. Nanomater. 2012, 2012, 1-22. [CrossRef]

26. Shkondin, E.; Takayama, O.; Panah, M.E.A.; Liu, P.; Larsen, P.V.; Mar, M.D.; Jensen, F.; Lavrinenko, A.V. Large-scale high aspect ratio Al-doped ZnO nanopillars arrays as anisotropic metamaterials. Opt. Mater. Express 2017, 7, 1606. [CrossRef]

27. Marcus, C.N.; Paul, A.W. ZnO tetrapod nanocrystals. Mater. Today 2007, 10, 50-54.

28. Septiani, N.L.W.; Kaneti, Y.V.; Yuliarto, B.; Nugraha; Dipojono, H.K.; Takei, T.; You, J.; Yamauchi, Y. Hybrid nanoarchitecturing of hierarchical zinc oxide wool-ball-like nanostructures with multi-walled carbon nanotubes for achieving sensitive and selective detection of sulfur dioxide. Sens. Actuators B Chem. 2018, 261, 241-251. [CrossRef]

29. Kaneti, Y.V.; Septiani, N.L.W.; Saptiama, I.; Jiang, X.; Yuliarto, B.; Shiddiky, M.J.A.; Fukumitsu, N.; Kang, Y.-M.; Golberg, D.; Yamauchi, Y. Self-sacrificial templated synthesis of a three-dimensional hierarchical macroporous honeycomb-like $\mathrm{ZnO} / \mathrm{ZnCo}_{2} \mathrm{O}_{4}$ hybrid for carbon monoxide sensing. J. Mater. Chem. A 2019, 7, 3415-3425. [CrossRef]

30. Septiani, N.L.W.; Saputro, A.G.; Kaneti, Y.V.; Maulana, A.L.; Fathurrahman, F.; Lim, H.; Yuliarto, B.; Nugraha; Dipojono, H.K.; Golberg, D.; et al. Hollow zinc oxide microsphere-multiwalled carbon nanotube composites for selective detection of sulfur dioxide. ACS Appl. Nano Mater. 2020, 3, 8982-8996. [CrossRef]

31. Mercedes, M.M.; Marcos, E.C.; Ubogui, J.; Ruiz, R.; Fabio, D.S.; dos Santos Claro, P.C.; Francisco, J.I. Simultaneous detection and photocatalysis performed on a 3D graphene/ZnO hybrid platform. Langmuir 2020, 36, 2231-2239.

32. Li, Z.; Zhang, L.; He, X.; Chen, B. Urchin-like ZnO-nanorod arrays templated growth of ordered hierarchical Ag/ZnO hybrid arrays for surface-enhanced Raman scattering. Nanotechnology 2020, 31, 165301. [CrossRef]

33. Tangsuwanjinda, S.; Chen, Y.-Y.; Lai, C.-H.; Jhou, G.-T.; Chiang, Y.-W.; Cheng, H.-M. Microporous oxide-based surface-enhanced raman scattering film for quadrillionth detection of mercury ion(II). Processes 2021, 9, 794. [CrossRef]

34. Zhao, Y.; Li, W.; Pan, L.; Zhai, D.; Wang, Y.; Li, L.; Cheng, W.; Yin, W.; Wang, X.; Xu, J.; et al. ZnO-nanorods/graphene heterostructure: A direct electron transfer glucose biosensor. Sci. Rep. 2016, 6, 32327. [CrossRef]

35. Perumal, V.; Hashim, U.; Gopinath, S.C.B.; Haarindraprasad, R.; Foo, K.L.; Balakrishnan, S.R.; Poopalan, P. Spotted nanoflowers': Gold-seeded zinc oxide nanohybrid for selective bio-capture. Sci. Rep. 2015, 6, 12231. [CrossRef]

36. Xie, Q.; Ma, Y.; Wang, X.; Zeng, D.; Wang, L.; Mai, L.; Peng, D.L. Electrostatic assembly of sandwich-like Ag-C@ZnO-C@Ag-C hybrid hollow microspheres with excellent high-rate lithium storage properties. ACS Nano 2016, 10, 1283-1291. [CrossRef]

37. Ahmad, R.; Tripathy, N.; Hahn, Y.; Umar, A.; Ibrahim, A.A.; Kim, S.H. A robust enzymeless glucose sensor based on CuO nanoseed modified electrodes. Dalton Trans. 2015, 44, 12488-12492. [CrossRef] [PubMed]

38. Zhu, G.; Xu, H.; Xiao, Y.; Liu, Y.; Yuan, A.; Shen, X. Facile fabrication and enhanced sensing properties of hierarchically porous $\mathrm{CuO}$ architectures. ACS Appl. Mater. Interfaces 2012, 4, 744-751. [CrossRef]

39. Krasovska, M.; Gerbreders, V.; Sledevskis, E.; Gerbreders, A.; Mihailova, I.; Tamanis, E.; Ogurcovs, A. Hydrothermal synthesis of $\mathrm{ZnO}$ nanostructures with controllable morphology change. CrystEngComm 2020, 22, 1346-1358.

40. Alfaro Cruz, M.R.; Ceballos-Sanchez, O.; Luévano-Hipólito, E.; Torres-Martínez, L.M. ZnO thin films deposited by RF magnetron sputtering: Effects of the annealing and atmosphere conditions on the photocatalytic hydrogen production. Int. J. Hydrogen Energy 2018, 43, 10301-10310. [CrossRef]

41. Lin, H.F.; Liao, S.C.; Hu, C.T. A new approach to synthesize $\mathrm{ZnO}$ tetrapod-like nanoparticles with DC thermal plasma technique. J. Cryst. Growth 2009, 311, 1378. [CrossRef]

42. Ko, T.S.; Yang, S.; Hsu, H.C.; Chu, C.P.; Lin, H.F.; Liao, S.C.; Lu, T.C.; Kuo, H.C.; Hsieh, W.F.; Wang, S.C. ZnO nanopowders fabricated by dc thermal plasma synthesis. Mater. Sci. Eng. B 2006, 134, 54-58. [CrossRef]

43. Cao, F.; Guo, S.; Ma, H.; Yang, G.; Yang, S.; Gong, J. Highly sensitive nonenzymatic glucose sensor based on electrospun copper oxide-doped nickel oxide composite microfibers. Talanta 2011, 86, 214-220. [CrossRef]

44. Zheng, B.; Liu, G.; Yao, A.; Xiao, Y.; Du, J.; Guo, Y.; Xiao, D.; Hu, Q.; Choi, M.M.F. A sensitive AgNPs/CuO nanofibers non-enzymatic glucose sensor based on electrospinning technology. Sens. Actuators B Chem. 2014, 195, 431-438. [CrossRef]

45. Lu, W.; Sun, Y.; Dai, H.; Ni, P.; Jiang, S.; Wang, Y.; Li, Z.; Li, Z. CuO nanothorn arrays on three-dimensional copper foam as an ultra-highly sensitive and efficient nonenzymatic glucose sensor. RSC Adv. 2016, 6, 16474-16480. [CrossRef]

46. Zhuang, Z.; Su, X.; Yuan, H.; Sun, Q.; Xiao, D.; Choi, M.M.F. An improved sensitivity non-enzymatic glucose sensor based on a $\mathrm{CuO}$ nanowire modified $\mathrm{Cu}$ electrode. Analyst 2008, 133, 126-132. [CrossRef]

47. Liu, S.; Wang, Z.; Wang, F.; Yu, B.; Zhang, T. High surface area mesoporous CuO: A high-performance electrocatalyst for non-enzymatic glucose biosensing. RSC Adv 2014, 4, 33327. [CrossRef]

48. Luo, S.; Su, F.; Liu, C.; Li, J.; Liu, R.; Xiao, Y.; Li, Y.; Liu, X.; Cai, Q. A new method for fabricating a CuO/TiO 2 nanotube arrays electrode and its application as a sensitive nonenzymatic glucose sensor. Talanta 2011, 86, 157. [CrossRef] [PubMed]

49. Foroughi, F.; Rahsepar, M. Microwave-assisted synthesis of graphene modified CuO nanoparticles for voltammetric enzyme-free sensing of glucose at biological pH values. Microchim. Acta 2018, 185, 57. [CrossRef] 